\title{
Effect of Activating Solution Modulus on the Synthesis of Sustainable Geopolymer Binders Using Spent Oil Bleaching Earths as Precursor
}

\author{
P. Delgado-Plana ${ }^{1}$, A. Rodríguez-Expósito ${ }^{1}$, S. Bueno-Rodríguez ${ }^{1,2}$, L. Pérez-Villarejo $\left.{ }^{2,3}{ }^{(}\right)$, D. M. Tobaldi ${ }^{4,5}{ }^{(1)}$, \\ J. A. Labrincha ${ }^{4}$ and D. Eliche-Quesada ${ }^{1,2, *(\mathbb{D})}$
}

1 Department of Chemical, Environmental, and Materials Engineering, Campus Las Lagunillas, Higher Polytechnic School of Jaén, University of Jaén, s/n, 23071 Jaén, Spain; pdplana@ujaen.es (P.D.-P.); are00011@red.ujaen.es (A.R.-E.); jsbueno@ujaen.es (S.B.-R.)

2 Center for Advanced Studies in Earth Sciences, Energy and Environment (CEACTEMA), Campus Las Lagunillas, University of Jaén, s/n, 23071 Jaén, Spain; lperezvi@ujaen.es

3 Department of Chemical, Environmental, and Materials Engineering, Campus Científico-Tecnológico, Higher Polytechnic School of Linares, University of Jaén, Cinturón Sur s/n, 23700 Linares, Spain

4 Department of Materials and Ceramic Engineering \& CICECO-Aveiro Institute of Materials, University of Aveiro, 3810-193 Aveiro, Portugal; david.tobaldi@ua.pt (D.M.T.); jal@ua.pt (J.A.L.)

5 CNR Nanotec, Campus Ecoteckne, Institute of Nanotechnology, 73100 Lecce, Italy

* Correspondence: deliche@ujaen.es; Tel.: +34-953-211-861

Citation: Delgado-Plana, P.; Rodríguez-Expósito, A.; Bueno-Rodríguez, S.; Pérez-Villarejo, L.; Tobaldi, D.M.; Labrincha, J.A.; Eliche-Quesada, D. Effect of Activating Solution Modulus on the Synthesis of Sustainable Geopolymer Binders Using Spent Oil Bleaching Earths as Precursor. Sustainability 2021, 13, 7501. https://doi.org/ $10.3390 /$ su13137501

Academic Editor: Rishi Gupta

Received: 14 June 2021

Accepted: 2 July 2021

Published: 5 July 2021

Publisher's Note: MDPI stays neutral with regard to jurisdictional claims in published maps and institutional affiliations.

Copyright: (c) 2021 by the authors. Licensee MDPI, Basel, Switzerland. This article is an open access article distributed under the terms and conditions of the Creative Commons Attribution (CC BY) license (https:// creativecommons.org/licenses/by/ $4.0 /)$.

\begin{abstract}
The valorization of spent oil bleaching earths (SOBE) is crucial for the protection of the environment and the reuse of resources. In this research, alkali-activated binders were manufactured at room temperature using $\mathrm{SOBE}$ as a precursor by varying the mass ratio between the activating solutions of sodium silicate $\left(\mathrm{Na}_{2} \mathrm{SiO}_{3}\right)$ and $6 \mathrm{M}$ sodium hydroxide $(\mathrm{NaOH})$ (activating solution modulus) $\left(\mathrm{Na}_{2} \mathrm{SiO}_{3} / \mathrm{NaOH}\right.$ ratio $\left.=1 / 1 ; 1 / 2 ; 1 / 3 ; 1 / 4\right)$ to investigate the influence on the technological properties of the materials. This process intends to evaluate the potential of SOBE, heat-treated at $550{ }^{\circ} \mathrm{C}(1 \mathrm{~h})$, as a precursor of the reaction (source of aluminosilicates). Samples produced with higher amounts of sodium silicate developed a denser structure, with lower porosity and a higher amount of geopolymer gel. Maximum flexural (8.35 MPa) and compressive (28.4 MPa) strengths of samples cured at room temperature for 28 days were obtained with a $\mathrm{Na}_{2} \mathrm{SiO}_{3} / \mathrm{NaOH}$ mass ratio of $1 / 1$. The study demonstrates that SOBE waste can be used as a precursor in the manufacture of geopolymer binders that show a good compromise between physical, mechanical and thermally insulating characteristics.
\end{abstract}

Keywords: spent bleaching earth; geopolymers; activating solution; activator modulus; compressive strength; microstructure

\section{Introduction}

Ordinary Portland cement (OPC) is the most widely used binding material in construction, being one of the materials with the highest production worldwide, with a production in 2016 of $4174 \mathrm{Mt}$, corresponding to a growth of 2.3\% compared to 2015 [1]. The global cement industry is one of the main greenhouse-gas (GHG)-emitting contributors as it generates $800 \mathrm{~kg} \mathrm{CO}_{2}$ for each ton of Portland cement produced [2]. In order to meet environmental objectives, this industry is seeking alternative experimental ways to develop cements that require less energy to manufacture and emit less polluting gases into the atmosphere. Its contribution corresponds to about $8 \%$ of global $\mathrm{CO}_{2}$ emissions (2.5 Gt/year), aggravating global warming and its consequences [3,4]. Alkali-activated binders, or geopolymers, constitute an environmentally friendlier alternative, since $\mathrm{CO}_{2}$ emissions can be reduced by $20-50 \%$ in comparison to OPC [5-7]. Hardening occurs when reactive aluminosilicates come into contact with an alkaline solution (activator) [8,9]. In 
a strongly alkaline media, the reactive species of the solid precursor dissolve and then generate hydroxylated oligomers of the $\mathrm{Si}(\mathrm{OH})_{4}{ }^{-}$and $\mathrm{Al}(\mathrm{OH})_{4}{ }^{-}$types. During the polycondensation reaction, the tetrahedral units alternately join to form amorphous reticules that constitute the geopolymeric matrix $[8,10]$. Geopolymers have attracted considerable attention due to their compressive strength, low permeability, good chemical resistance and durability to acid and sulfate attack, as well as excellent thermal fire resistance [11-17].

Metakaolin, generated by thermal activation of kaolinite, is the benchmark precursor [18-21]. Other calcined clays have been tested [22,23], but all these sources are natural and non-renewable. Moreover, their activation requires a pre-calcination stage that is energy consuming and generates emissions. Several industrial wastes were then tested as candidates: fly ash, mainly from coal combustion but also from biomass burning; slags; waste glass; and spent zeolites, etc. [24-29].

The most commonly employed alkaline activators are sodium silicate $\left(\mathrm{Na}_{2} \mathrm{SiO}_{3}\right)$ or potassium silicate $\left(\mathrm{K}_{2} \mathrm{SiO}_{3}\right)$ and sodium hydroxide $(\mathrm{NaOH})$ or potassium hydroxide $(\mathrm{KOH})[30]$. The hydroxide concentration, the silicate/hydroxide ratio and the alkaline cation employed ( $\mathrm{Na}$ and/or $\mathrm{K}$ ) are determinants in the geopolymerization process by determining the chemical reactions that take place [23,31-35]. Alkaline silicate hydrate is the activator with the highest activation potential compared to other activators, such as hydroxides, because it has dissolved silica particles that react in the geopolymerization process, resulting in alkaline-activated cements with better mechanical performance and durability [36]. Therefore, the geopolymerization process depends on many factors including the precursor and activator used, the solid/liquid ratio, the curing temperature and the aging time, which play a role in the mechanical and durability properties of the geopolymers [37-40]

Spent oil bleaching earth (SOBE) is a waste product obtained in the refining process of edible crude oil. It is estimated that 120 million tons of oil are processed with bleaching earth worldwide, generating 2.5 million tons of spent bleaching earth as residue [41]. Moreover, the serious fire and contamination risks that arise during storage and disposal of spent bleaching earth require appropriate technical solutions. The current treatment of SOBE residue is not in line with the new circular economy policies promoted by the European Union, since in most cases it is disposed of in landfills [42]. New technologies that allow oil recovery and treatment of the earths, aiming to convert them into useful products are then needed [43]. Currently, studies are being carried out for its possible valorization as an adsorbent in wastewater treatment [43-46], fertilizer [47] and chicken feeding [48], as well as for its use as a raw material of different construction materials [49,50].

Oil bleaching earths are depleted bentonites, silica and alumina being the major constituents. They consist of $20-40 \mathrm{wt} \%$ residual oil, metallic impurities and other organic compounds [51]. Once the oil and organic compounds are removed, due to their composition they can be used as binders in the manufacture of geopolymers.

The manufacture of geopolymers at room temperature using SOBE as a precursor is challenging and constitutes the major novelty of this work. The effect of the modulus of the alkaline activator (mass ratio between sodium silicate and sodium hydroxide $\mathrm{Na}_{2} \mathrm{SiO}_{3} / \mathrm{NaOH}$ solutions) on the geopolymerization reaction was tested. Microstructural development and relevant properties of hardened samples were evaluated and discussed.

\section{Materials and Methods}

\subsection{Raw Material}

The spent oil bleaching earth (SOBE) residue was obtained from an olive oil production plant located in Vilches (Jaén, Spain). To dehydrate the residue received, it was dried in an oven at $105^{\circ} \mathrm{C}$. The sample had a moisture content of $6.66 \mathrm{wt} \%$. It was then ground in a ball mill and sieved to a particle size of less than $100 \mu \mathrm{m}$. A thermogravimetric analysis (TGA)-thermodifferential analysis (DTA) of the dry residue was carried out to determine the temperature of the heat treatment to which the residue should be subjected. DTA-TGA was carried out on a Mettler Toledo thermal analyser model TGA/DSC 1. About $10 \mathrm{mg}$ 
of the OBE sample (with a particle size of $<1 \mathrm{~mm}$ ) was placed in an aluminium crucible with an air flow of $50 \mathrm{~mL} / \mathrm{min}$ and a heating rate of $10^{\circ} \mathrm{C} / \mathrm{min}$ from $30^{\circ} \mathrm{C}$ to $900{ }^{\circ} \mathrm{C}$. The TGA-DTA analysis (Figure 1) indicated that combustion of the residue takes place between 180 and $550{ }^{\circ} \mathrm{C}$. The combustion of the oil takes place in two stages. The mass loss of the residue between $100-415{ }^{\circ} \mathrm{C}(39.05 \mathrm{wt} \%)$, exothermic peak centered at $375{ }^{\circ} \mathrm{C}$ and the weight loss between $415-550{ }^{\circ} \mathrm{C}(16.8 \mathrm{wt} \%)$, as indicated by the more intense exothermic peak centred at $473{ }^{\circ} \mathrm{C}$. At $550^{\circ} \mathrm{C}$ combustion of the residue ends. Therefore, the calcination temperature of the $\mathrm{OBE}$ residue was $550{ }^{\circ} \mathrm{C}$ for one hour in a Carbolite $1200 \mathrm{~F}$ kiln with a heating rate of $10^{\circ} \mathrm{C} / \mathrm{min}$ and a one-hour dwell time.

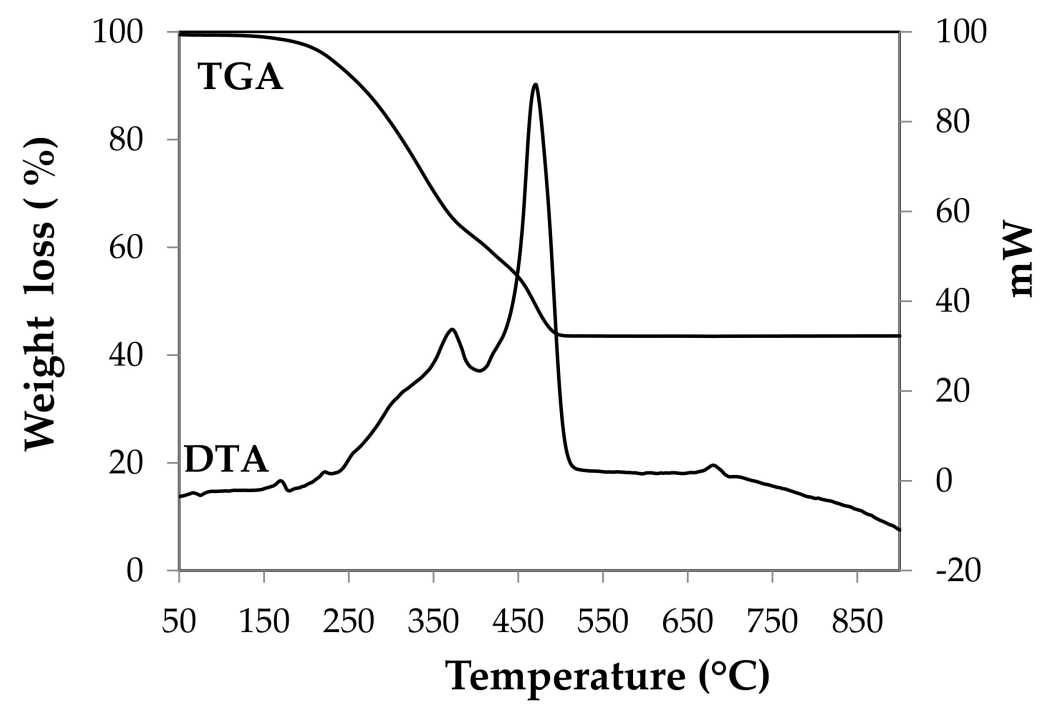

Figure 1. TGA-DTA analysis of the spent oil bleaching earth (SOBE).

The determination of the chemical composition of the SOBE residue after calcination at $550{ }^{\circ} \mathrm{C}$ was determined by X-ray fluorescence (XRF), using a Zetium Malvern Panalytical apparatus (Netherlands). The residue was composed of a significant content of $\mathrm{SiO}_{2}(68.4 \%)$ and $\mathrm{Al}_{2} \mathrm{O}_{3}(14.4 \%)$, which are elemental oxides for the development of the geopolymer structure (Table 1 ). The particle size of the calcined residue analysed with the Mastersize 2000 analyser from Malvern Instruments (Netherlands) was $\mathrm{d}(50)=137 \mu \mathrm{m}$ and $\mathrm{d}(90)=251 \mu \mathrm{m}$.

Table 1. Chemical composition of SOBE after calcination at $550{ }^{\circ} \mathrm{C}$.

\begin{tabular}{ccccccccccccccc}
\hline \multirow{2}{*}{$\begin{array}{c}\text { Raw } \\
\text { Material }\end{array}$} & $\mathrm{SiO}_{\mathbf{2}}$ & $\mathrm{Al}_{\mathbf{2}} \mathbf{O}_{\mathbf{3}}$ & $\mathrm{Fe}_{\mathbf{2}} \mathbf{O}_{\mathbf{3}}$ & $\mathbf{M g O}$ & $\mathbf{K}_{\mathbf{2}} \mathbf{O}$ & $\mathbf{C a O}$ & $\mathbf{T i O}_{\mathbf{2}}$ & $\mathbf{N a}_{\mathbf{2}} \mathbf{O}$ & $\mathbf{P}_{\mathbf{2}} \mathbf{O}_{\mathbf{5}}$ & $\mathbf{S O}_{\mathbf{3}}$ & $\mathbf{M n O}$ & $\mathbf{L O I}$ \\
\hline SOBE & 68.35 & 14.43 & 3.21 & 2.05 & 0.90 & 0.35 & 0.33 & 0.18 & 0.09 & 0.04 & 0.01 & 9.96 \\
\hline \multicolumn{10}{c}{ LOI: Loss On Ignition. }
\end{tabular}

The mineralogy of calcined SOBE powdered sample was studied by X-ray Diffraction (XRD), using Empyrean X-ray powder diffraction equipment with a PIXcel-3D detector of PANalytical (Malvern, The Netherlands) (CuK $\alpha$ radiation, $0.15418 \mathrm{~nm}, 45 \mathrm{kV}-40 \mathrm{~mA}$, $2 \theta=10-60^{\circ}$, step size $0.013^{\circ}$ and measurement time: $15 \mathrm{~min}$ ). HighScore software was used to identify the crystalline phases. Calcined SOBE residue has a mineralogical composition consisting of montmorillonite (82.4 wt\%) (PDF: 96-900-5020) and $\alpha$-quartz (17.6 wt $\%$ ) (PDF: 96-900-5020). Baseline deviation between $18-30^{\circ}(2 \theta)$ indicates an amorphous fraction in the residue (Figure 2). 


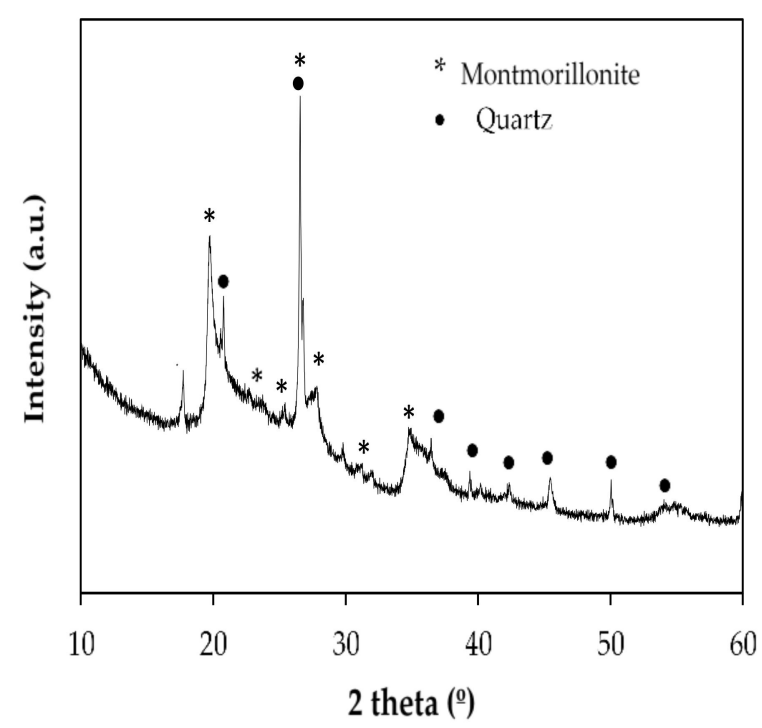

Figure 2. DRX of SOBE calcined at $550{ }^{\circ} \mathrm{C}$.

The morphology of the SOBE precursor calcined at $550^{\circ} \mathrm{C}$ was determined by scanning electron microscopy (SEM), using a JEOL SM 840 model (Akishima, Tokyo, Japan) assisted by energy dispersive $\mathrm{X}$-ray spectroscopy (EDS). Prior to observation, the samples were carbon-coated using JEOL JFC 1100 sputter coating. The micrograph is shown in Figure 3. A heterogeneous distribution of particles of different sizes and shapes can be observed.

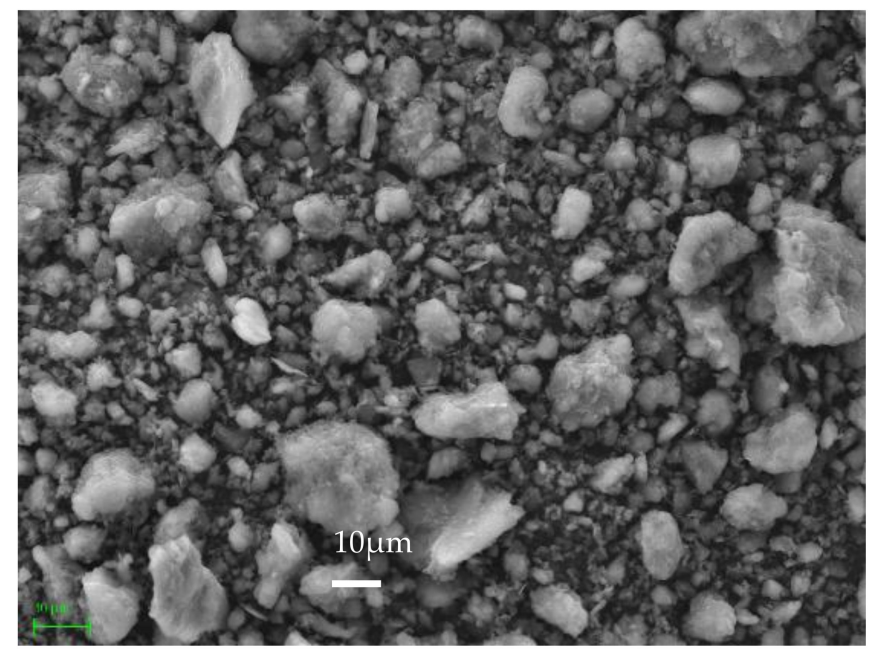

Figure 3. SEM micrograph of SOBE calcined at $550{ }^{\circ} \mathrm{C}$.

\subsection{Geopolymers Synthesis}

The activating solutions were prepared previously. Sodium hydroxide solutions (6 M) were prepared by dissolving $\mathrm{NaOH}$ pellets ( $98 \%$ purity, Panreac) in distilled water. The $\mathrm{NaOH}$ solution was cooled prior to the addition of the sodium silicate activating solution with the appropriate $\mathrm{Na}_{2} \mathrm{SiO}_{3} / \mathrm{NaOH}$ mass ratio $(1: 1 ; 1: 2 ; 1: 3 ;$ and $1: 4)$. The activating solution used was obtained by addition to the $\mathrm{NaOH}$ solution $(6 \mathrm{M})$ of the appropriate amount of sodium silicate solution Panreac $\left(29.2 \% \mathrm{SiO}_{2} ; 8.9 \% \mathrm{Na}_{2} \mathrm{O}\right.$; and $\left.61.9 \% \mathrm{H}_{2} \mathrm{O}\right)$.

The geopolymers were prepared by mixing the SOBE-calcined raw material (200 g) and the alkaline activating solution in a planetary mixer Proeti for $90 \mathrm{~s}$. The rotation speed of the blade on its axis was $140 \pm 5 \mathrm{~min}^{-1}$ and the translation speed around the center of the container was $62.5 \pm 5 \mathrm{~min}^{-1}$. The liquid/binder ratio was kept constant and equal to 1.4, the whole activating solution (including solids dissolved) was considered as the liquid phase and the SOBE precursor as the binder. Subsequently, the material adhering to 
the vessel walls was removed with a spatula and mixed for another $30 \mathrm{~s}$. The fresh pastes were poured into $60 \times 10 \times 10 \mathrm{~cm}$ stainless steel moulds and subjected to 60 strokes on a Proeti punching table to remove air bubbles trapped in the paste and to achieve a higher compaction. The moulded pastes were cured at room temperature, and wrapped in cling film for $24 \mathrm{~h}$. The cured pastes were then demoulded and stored at room temperature until the test ages of 7 and 28 days. The mixtures have been designated by SOBE-x:y where $x: y$ is the mass ratio $\mathrm{Na}_{2} \mathrm{SiO}_{3}: \mathrm{NaOH}$. The mix proportions of the synthesised geopolymers can be seen in Table 2.

Table 2. Mix proportions for assessed samples.

\begin{tabular}{|c|c|c|c|c|c|c|c|c|}
\hline Geopolymer & $\begin{array}{l}\text { Water/Binder } \\
\text { (Mass Ratio) }\end{array}$ & $\mathrm{NaOH}(\mathrm{g})$ & $\mathrm{Na}_{2} \mathrm{SiO}_{3}$ & Water (g) & Ms & $\begin{array}{c}\mathrm{Na}+ \\
\left(\mathrm{mol} \mathrm{kg}^{-1}\right)\end{array}$ & $\begin{array}{c}\text { Si/Al } \\
\text { (Molar Ratio) }\end{array}$ & $\begin{array}{c}\mathrm{Si} / \mathrm{Na} \\
\text { (Molar Ratio) }\end{array}$ \\
\hline G-SOBE-1:1 & 0.71 & 27.54 & 140 & 112.5 & 1.27 & 6 & 5.22 & 2.75 \\
\hline G-SOBE-1:2 & 0.76 & 36.72 & 93.32 & 149.93 & 0.78 & 6 & 4.82 & 2.34 \\
\hline G-SOBE-1:3 & 0.79 & 41.31 & 70.00 & 168.69 & 0.56 & 6 & 4.62 & 2.16 \\
\hline G-SOBE-1:4 & 0.81 & 44.07 & 56.00 & 179.93 & 0.44 & 6 & 4.50 & 2.06 \\
\hline
\end{tabular}

\subsection{Characterisation of Geopolymers}

Degree of reaction was used in addition to characterisation techniques to dissolve the aluminosilicate gels formed [52]. For determination, $1 \mathrm{~g}$ of ground and sieved geopolymer $(100 \mu \mathrm{m})$ was attacked with a $250 \mathrm{~mL}$ solution of $\mathrm{HCl}(1: 20)$ for $3 \mathrm{~h}$. The solution was then filtered, and the insoluble residue was washed with deionized water and dried to constant weight and calcined at $1000{ }^{\circ} \mathrm{C}(3 \mathrm{~h})$. The degree of reaction is calculated according to Equation (1):

$$
\text { Degree of reaction }=(1-\text { calcined mass }) \times 100
$$

The flexural strength of the geopolymers ( 5 samples for each series) at 7 and 28 days was determined with an MTS Insight 5 machine (Eden Prairie, MN, USA) of $5 \mathrm{kN}$ capacity with a displacement speed of $0.2 \mathrm{~mm} / \mathrm{min}$ according to UNE-EN 1015-11:2020 [53]. The results shown are the average of 5 repeated samples. The flexural strength is determined according to Equation (2):

$$
\sigma_{\mathrm{F}}=1.5 \frac{F l}{b d^{2}}
$$

where $F$ is the load $(\mathrm{N}) ; l$ is the distance between the axes of the support rollers $(\mathrm{mm}) ; b$ is the width of the specimen (mm); and $d$ is the thickness of the specimen (mm).

The compressive strength of the geopolymers was measured with a MST $8101(100 \mathrm{kN})$ (Eden Prairie, MN, USA) universal testing machine at 7 and 28 days with a displacement of $2.0 \mathrm{~mm} / \mathrm{min}$ according to UNE-EN105-11:2020 [53]. The results shown are an average of five samples. The compressive strength is given by Equation (3):

$$
\sigma_{C}=\frac{F}{S}
$$

with $F$ the force $(\mathrm{N})$; $S$ the area of the specimen face under load; and $\sigma_{\mathrm{c}}$ the compressive strength (MPa).

The bulk density $(\varphi a)$ of the geopolymers at 28 days was calculated according to UNEEN 1015-10:2020 [54]. The real density $(\varphi r)$ was measured using a picnometer employing gasoline and fine crushed samples with particle size less than $63 \mu \mathrm{m}$.

The total porosity $\left(P_{T}\right)$ was calculated according to the following Equation (4):

$$
P T=\left(1-\frac{\varphi a}{\varphi r}\right) * 100
$$


Water absorption $\left(W_{a}\right)$ was carried out by immersing the dry samples in water at room temperature for $24 \mathrm{~h}$ and comparing the wet mass $\left(\mathrm{m}_{\mathrm{h}}\right)$ with the dry mass $\left(\mathrm{m}_{\mathrm{d}}\right)$ according to Equation (5):

$$
W a=\frac{(\mathrm{mh}-\mathrm{ms})}{\mathrm{md}} * 100
$$

The thermal conductivity of the geopolymers after 28 days of curing was determined at $20{ }^{\circ} \mathrm{C}$ according to ISO 8302:1991 [55] using a FOX 50 heat-flow meter (TA Instruments, New Castle, DE, USA).

The samples were analysed using a Vertex 70 Bruker (Billerica, Massachusetts, United States) Fourier transform infrared spectrophotometer (FTIR). Infrared scans were carried out in the wavenumber range from 400 to $4000 \mathrm{~cm}^{-1}$, with a resolution of $4 \mathrm{~cm}^{-1}$, and 100 cycles were performed to record the spectrum. Mineralogical analysis and micrograph images of the geopolymers were performed by XRD and SEM-EDS, respectively, using the same conditions as for the raw material. Quantitative phase analysis (QPA), not accounting for the amorphous phase, was assessed using the Rietveld method. The Rietveld dataanalyses-recorded XRD patterns were evaluated using the GSAS software package and its graphical interface EXPGUI $[56,57]$. Those parameters were refined: scale factors, zeropoint, 10 coefficients of the shifted Chebyshev function to fit the background, unit cell parameters. The profile was modelled using the Thompson-Cox-Hasting formulation of the pseudo-Voigt function [58], and two Lorentzian terms (LX and LY), one Gaussian term ( $\mathrm{Gw}$, which is angle independent), peak correction for asymmetry, as well as sample displacement effects, were refined. The starting atomic parameters for the refined phases (i.e., montmorillonite and quartz) were taken from the literature $[59,60]$.

\section{Results and Discussion}

\subsection{Reaction Degree}

The reaction degree of the geopolymers after 28 days curing as a function of the activation solution modulus, $\mathrm{Na}_{2} \mathrm{SiO}_{3} / \mathrm{NaOH}$ mass ratio, is presented in Table 3. $\mathrm{HCl}$ extraction dissolves sodium aluminosilicate, calcium aluminosilicate and carbonate phases [61]. The reaction degree tends to increase in samples prepared with higher $\mathrm{Na}_{2} \mathrm{SiO}_{3} / \mathrm{NaOH}$ mass ratios, indicating the formation of a greater amount of $\mathrm{N}-\mathrm{A}-\mathrm{S}-\mathrm{H}$ geopolymer gel.

Table 3. Reaction degree of the samples.

\begin{tabular}{ccccc}
\hline Sample & G-SOBE-1:1 & G-SOBE-1:2 & G-SOBE-1:3 & G-SOBE-1:4 \\
\hline Reaction degree (\%) & 52.5 & 47.3 & 45.7 & 43.5 \\
\hline
\end{tabular}

\subsection{Fourier Transform Infrared Spectroscopy (FTIR)}

FTIR spectra of the raw material (SOBE) and geopolymers after 28 days curing are shown in Figure 4. A broad band centered at $1035 \mathrm{~cm}^{-1}$, corresponding to the Si-O-Si groups, is observed in the raw material, together with a weak shoulder centered at $940 \mathrm{~cm}^{-1}$, related to the vibration of the $\mathrm{Al}-\mathrm{OH}$ bond of the bentonite [62]. The bands centered at 800 and $459 \mathrm{~cm}^{-1}$ are attributed to the stretching vibration of the Si-O bond [63,64]. Two bands are observed in the high-frequency region. A band centered at $3630 \mathrm{~cm}^{-1}$ associated with the Al-OH functional group [62] and the absorption bands located at $3400 \mathrm{~cm}^{-1}$ and $1617 \mathrm{~cm}^{-1}$, assigned to the stretching vibration and bending vibrations, respectively, are characteristic of the -OH groups of adsorbed water [65]. The geopolymers present similar patterns to the SOBE precursor, apart from the disappearance of the Al-OH functional group centered at $3630 \mathrm{~cm}^{-1}$ and of the Si-OH functional group centered at $459 \mathrm{~cm}^{-1}$. This may indicate that the montmorillonite layer reacts with the alkaline medium, giving rise to a geopolymeric gel [66] according to XRD data. The broad band between $1200 \mathrm{~cm}^{-1}$ and $900 \mathrm{~cm}^{-1}$ is associated with the asymmetric Si-O-Si vibration and the symmetric Al-O-Si bending vibration [67]. It can be observed that the Si-O-T (T:Si or Al) stretching vibration, centered on the precursor at $1035 \mathrm{~cm}^{-1}$, shifted to lower frequencies in the geopolymers 
(1004-994 $\left.\mathrm{cm}^{-1}\right)$. This change also indicates that the geopolymerization reaction has taken place due to the activation of the amorphous phase of the SOBE residue with the formation of N-A-S-H aluminosilicate gel, which means the condensation of Si-O tetrahedra as well as $\mathrm{SiO}_{4}$ and $\mathrm{AlO}_{4}$ in the geopolymer [40,68-70]. The band shift at lower frequencies may be due to an increase in the content of non-bridging oxygens, as well as to an increase in the amount of tetrahedral aluminum in the gel structure [27,71]. In all geopolymers, centered shoulders are also observed at $930 \mathrm{~cm}^{-1}$, which can be assigned to the formation of an Al-rich gel. Initially an aluminum-rich gel is formed, and with the progress of the reaction, when the aluminum is depleted the formation of a Si-rich gel begins [72]. The intensity of the band is also attributable to the amount of $\mathrm{Si}-\mathrm{O}$ or $\mathrm{Al}-\mathrm{O}$ in a tetrahedral configuration. The intensity decreases with a decreasing $\mathrm{Na}_{2} \mathrm{SiO}_{3} / \mathrm{NaOH}$ molar ratio of the activating solution [73]. Geopolymers synthesized using a $\mathrm{Na}_{2} \mathrm{SiO}_{3} / \mathrm{NaOH}=1 / 1$ mass ratio $(\mathrm{Ms}=1.27)$ show a more intense band, suggesting greater disorder in the formed gel $[68,74]$. These results are consistent with the differences in compressive strength, discussed below. The bands centered at $3300-3200 \mathrm{~cm}^{-1}$ and $1635 \mathrm{~cm}^{-1}$ indicate the presence of water molecules adsorbed on the surface or trapped in the large cavities of the polymeric network [75]. The intensity of such bands enhances when the $\mathrm{Na}_{2} \mathrm{SiO}_{3} / \mathrm{NaOH}$ mass ratio increases, probably due to a higher dissolution of the SOBE precursor, leading to the formation of more hydrated compounds according to the reaction degree data. The absorption bands around $1450 \mathrm{~cm}^{-1}$ and $866-870 \mathrm{~cm}^{-1}$ are typical of the C-O bond stretching of the $\mathrm{CO}_{3}$ vibrational groups that are present in the inorganic carbonates found in all the spectra of geopolymer samples due to the formation of sodium carbonate [76].

\subsection{Mineralogy of Geopolymer Binders}

Figure 5 shows XRD spectra of the precursor and geopolymer binders. Patterns are similar, being montmorillonite and quartz, the crystalline phases having been detected. The partial dissolution of montmorillonite upon geopolymerization, revealed by the FTIR analyses and confirmed by QPA results (Table 4) [77], and the increase in the amorphous phase are the most relevant observations. However, the fraction of montmorillonite that dissolves is small for all the activator modules used, as observed by other authors [78]. Quartz peaks remain almost unchanged, indicating its non-reactive character. The analysis confirms the low dissolution of the crystalline phases by the activating solutions. The amorphous hump at $18-30^{\circ}(2 \theta)$ in the SOBE precursor becomes more prominent and slightly shifts to $20-35^{\circ}(2 \theta)$ with the geopolymerization progress [79]. 


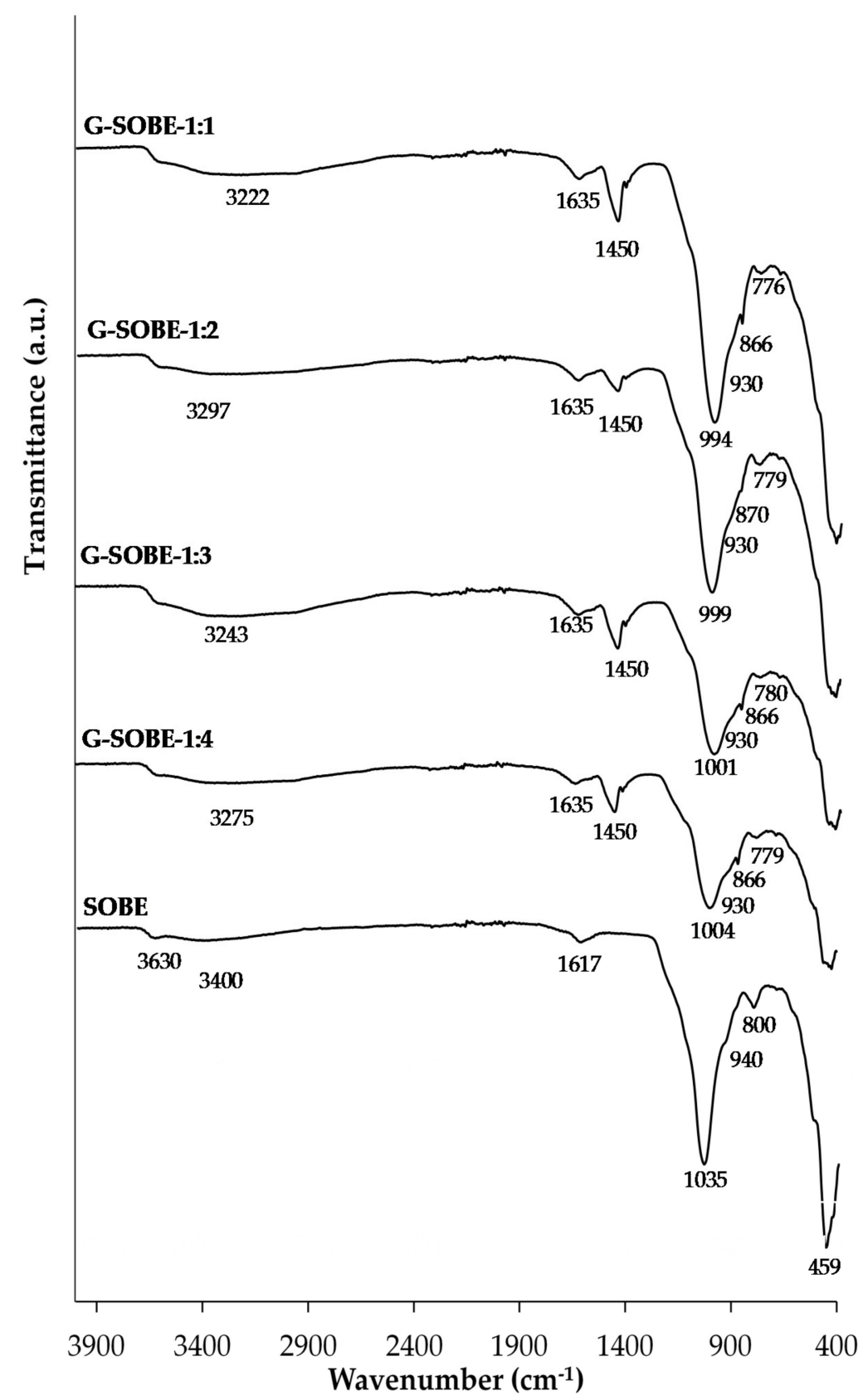

Figure 4. FTIR of SOBE and geopolymer binders. 


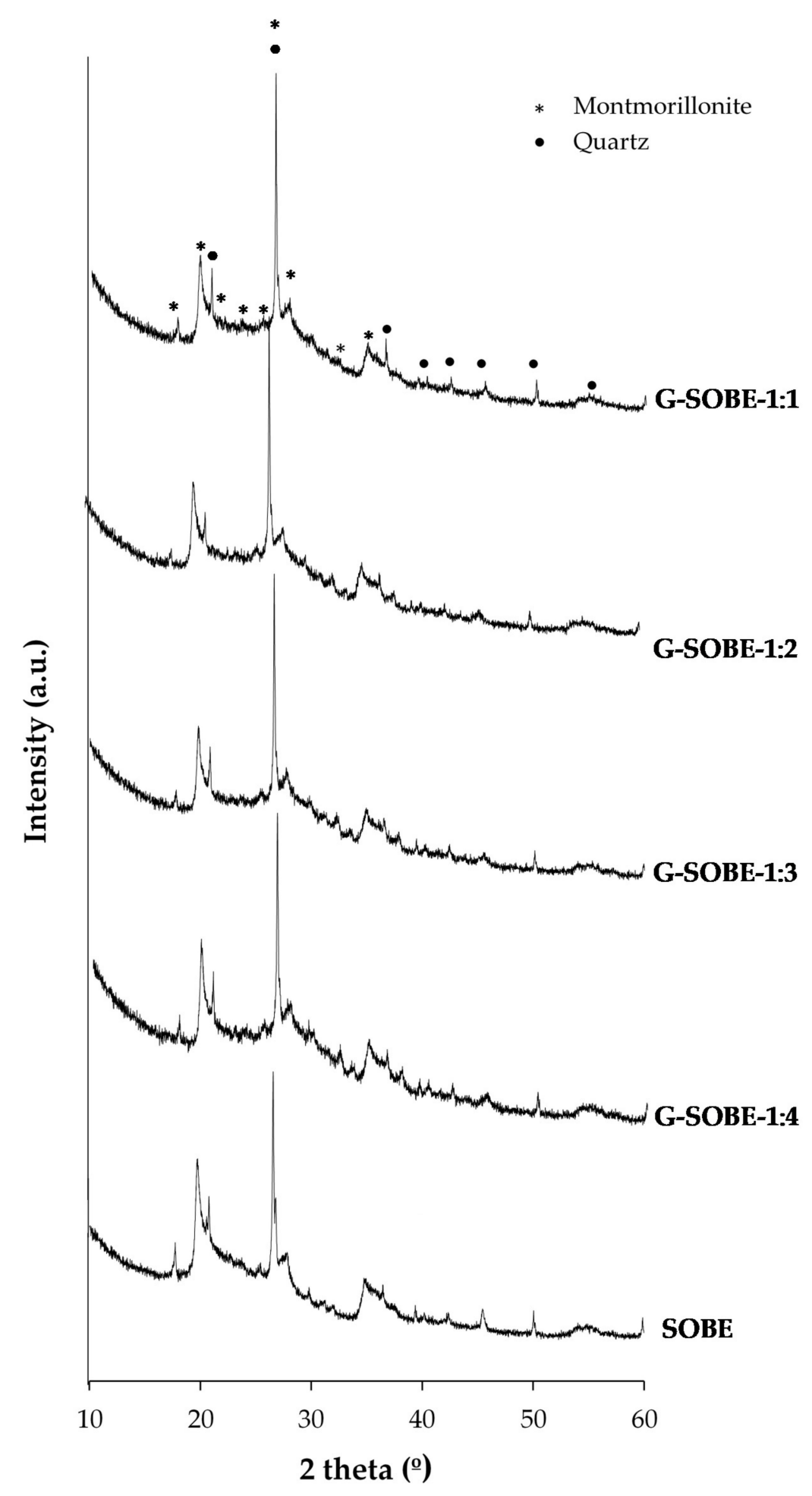

Figure 5. XRD of raw material and geopolymer cements as function of $\mathrm{Na}_{2} \mathrm{SiO}_{2} / \mathrm{NaOH}$ mass ratio of activating solution. 
Table 4. Quantitative crystalline phase composition as derived from the Rietveld refinements *.

\begin{tabular}{ccc}
\hline & \multicolumn{2}{c}{ Phase Composition (wt\%) } \\
\hline Sample & Montmorillonite & $\boldsymbol{\alpha}$-Quartz \\
\hline Raw material & $82.4 \pm 0.2$ & $17.6 \pm 0.3$ \\
G-SOBE-1:1 & $81.8 \pm 0.2$ & $18.2 \pm 0.2$ \\
G-SOBE-1:2 & $81.3 \pm 0.2$ & $18.7 \pm 0.3$ \\
G-SOBE-1:3 & $81.7 \pm 0.2$ & $18.3 \pm 0.5$ \\
G-SOBE-1:4 & $80.5 \pm 0.2$ & $19.5 \pm 0.3$ \\
\hline
\end{tabular}

* There were 3578 total observations for each refinement. The agreement factors of all the refinements were: $\chi^{2} \leq 4.92 ; R_{\mathrm{wp}} \leq 5.57 \%$; and $R_{\mathrm{p}} \leq 4.20 \%$.

\subsection{Bulk Density, Total Porosity and Water Absorption of Geopolymer Binders}

The values of bulk density, total porosity and water absorption of the geopolymers are shown in Figure 6. As expected, bulk density and total porosity or water absorption values followed an opposite tendency when the $\mathrm{Na}_{2} \mathrm{SiO}_{3} / \mathrm{NaOH}$ mass ratio of the activator changed. G-SOBE-1:1 specimens have a bulk density of $1828 \mathrm{~kg} / \mathrm{m}^{3}$, total porosity of $20.7 \%$ and water absorption of $4.35 \%$. As the $\mathrm{Na}_{2} \mathrm{SiO}_{3} / \mathrm{NaOH}$ mass ratio decreases, density decreases while total porosity and water absorption increases: G-SOBE-1:4 geopolymers show density $=1453 \mathrm{~kg} / \mathrm{m}^{3}$, total porosity $=37.9 \%$ and water absorption $=14.9 \%$. Samples prepared with lower $\mathrm{Na}_{2} \mathrm{SiO}_{3} / \mathrm{NaOH}$ mass ratios have more water (see Table 2). The water/binder ratio increases from 0.71 in G-SOBE-1:1 to 0.81 in G-SOBE-1:4 specimens; the removal of water will generate porosity [80]. Inadequate amounts of binder precursor and alkali solution results in less efficient dissolution of the precursor, with consequent creation of pores in the geopolymer matrix and the formation of a less homogeneous structure [81]. The ultimate removal of excess water upon drying will also create porosity. A decrease in the $\mathrm{Si} / \mathrm{Al}$ molar ratio tends to generate less dense structures as a consequence of slower geopolymerization, according to the degree of reaction data [82]. So, we have physical and chemical/reactive contributions to the observed tendencies.

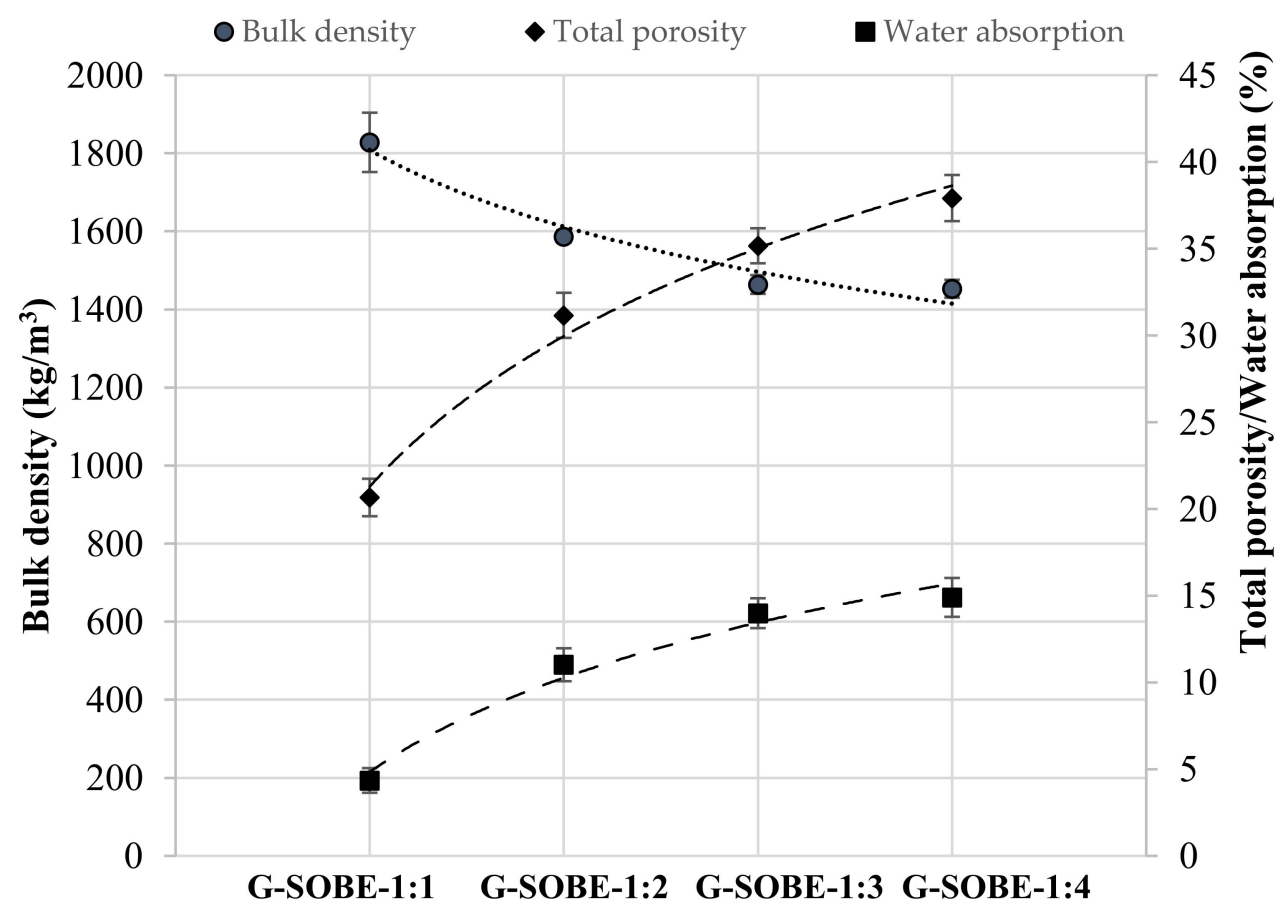

Figure 6. Bulk density, total porosity and water absorption of geopolymers after 28 days of curing as functions of the $\mathrm{Na}_{2} \mathrm{SiO}_{3} / \mathrm{NaOH}$ mass ratio. 


\subsection{Compressive and Flexural Strength of Geopolymer Binders}

Figure 7 shows the compressive strength of samples cured for 7 and 28 days. Values ranged from 10.1 to $17.9 \mathrm{MPa}$ (7 days) and 15.7 to $28.9 \mathrm{MPa}$ (28 days). An increase in the $\mathrm{Na}_{2} \mathrm{SiO}_{3} / \mathrm{NaOH}$ mass ratio enhances resistance, in direct relationship with higher compactness. Figure 8 shows a linear correlation between compressive strength and bulk density. The enhancement of soluble $\mathrm{Si}$, by using an activator with a higher modulus, extends the geopolymerization process and the formation of the N-A-S-H aluminosilicate gel responsible for the consolidation of the geopolymer matrix and the development of mechanical strength [83-87].

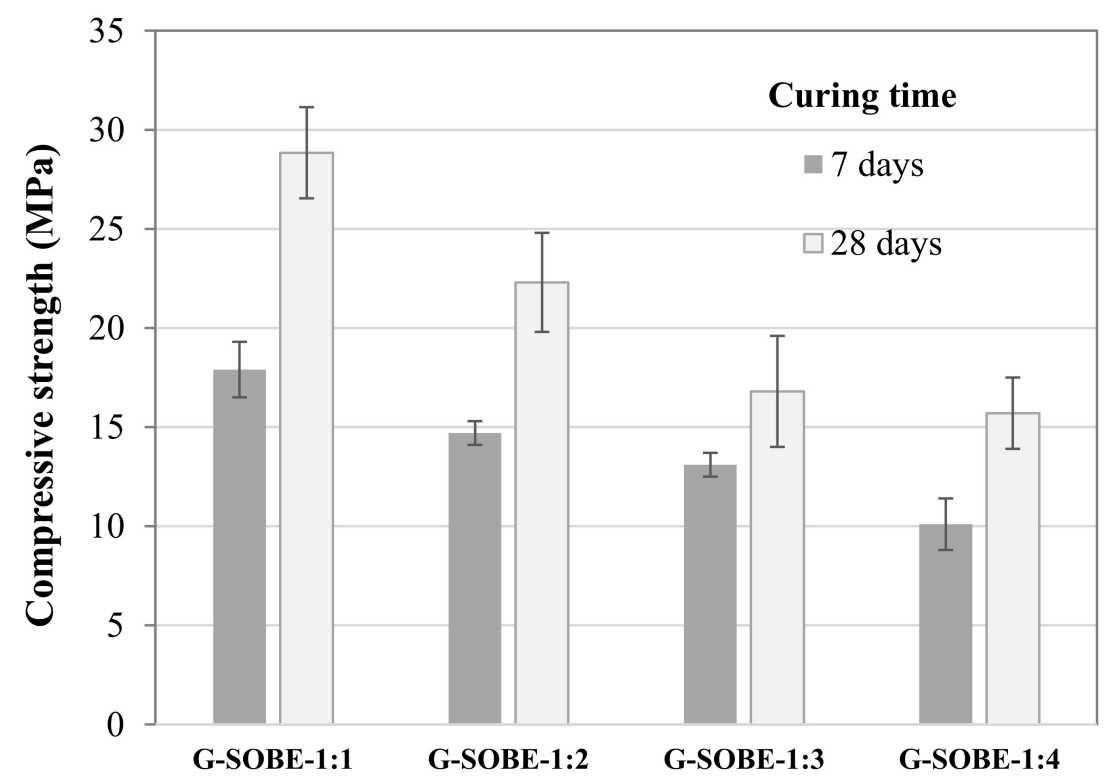

Figure 7. Compressive strength of samples cured for 7 and 28 days.

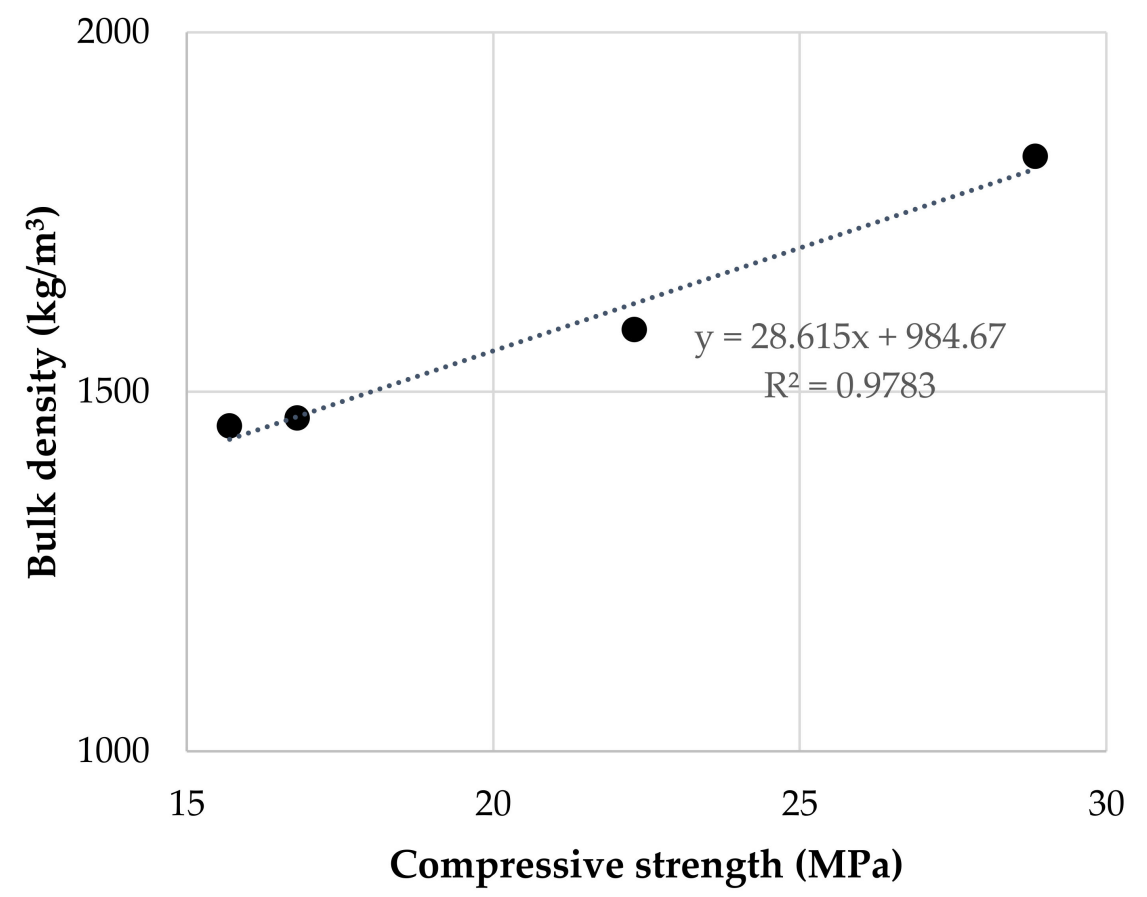

Figure 8. Relationship between bulk density and compressive strength of geopolymers cured for 28 days. 
The flexural strength values of the samples are shown in Figure 9. Between distinct formulations the changes follow the same trend in mechanical resistance after 28 days curing. However, differences after 7 days are minor, and sample G-SOBE-1:4 shows the maximum value (2.2 MPa). Progress with curing age is now more expressive, and resistance after 28 curing days is three to four times higher than at 7 days. Interestingly, it was observed that flexural strength values are only about three times lower than corresponding compressive resistances in samples cured for 28 days.

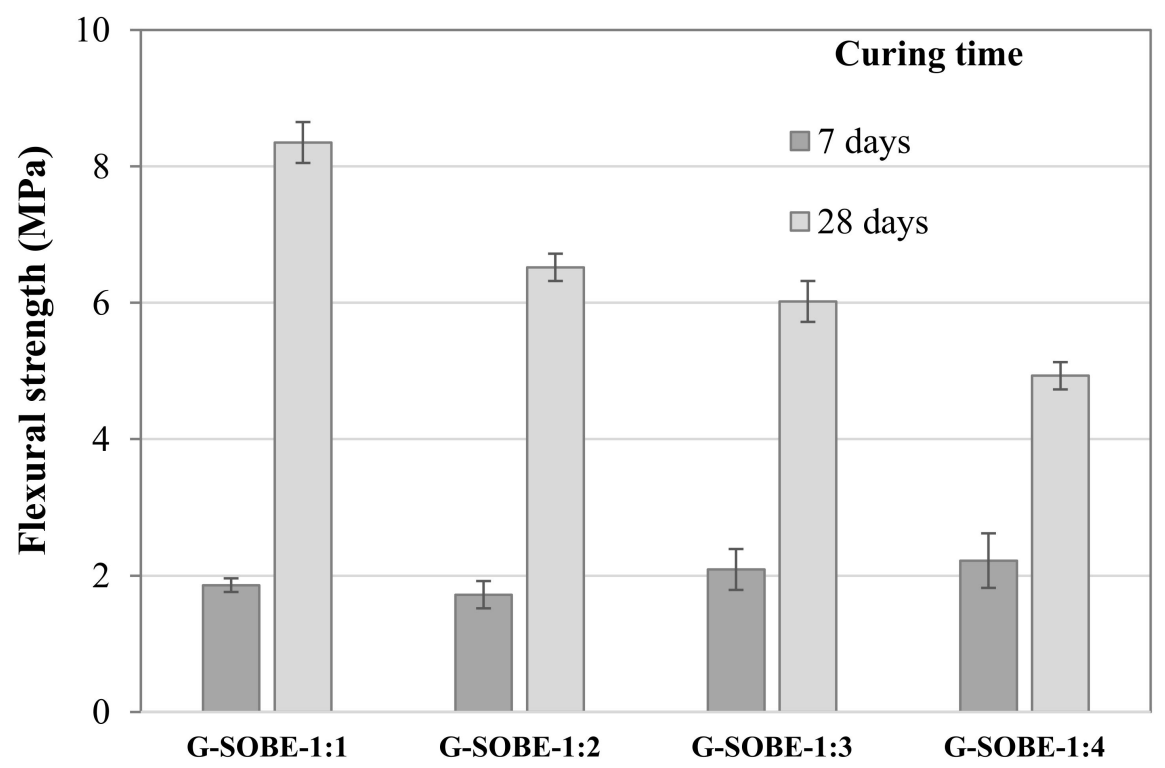

Figure 9. Flexural strength of samples cured for 7 and 28 days.

\subsection{Thermal Conductivity}

The geopolymers showed thermal conductivity values in the range $0.30-0.41 \mathrm{~W} / \mathrm{mK}$ (Figure 10), being lower in samples less dense (the ones prepared with a lower $\mathrm{Na}_{2} \mathrm{SiO}_{3} / \mathrm{NaOH}$ mass ratio). As expected, there is an inverse relationship between thermal conductivity and porosity [88]. In general, geopolymers exhibit lower thermal conductivity values than Portland cement $(1.5 \mathrm{~W} / \mathrm{mK})[89,90]$, due to the existence of pores in the microstructure $[91,92]$.

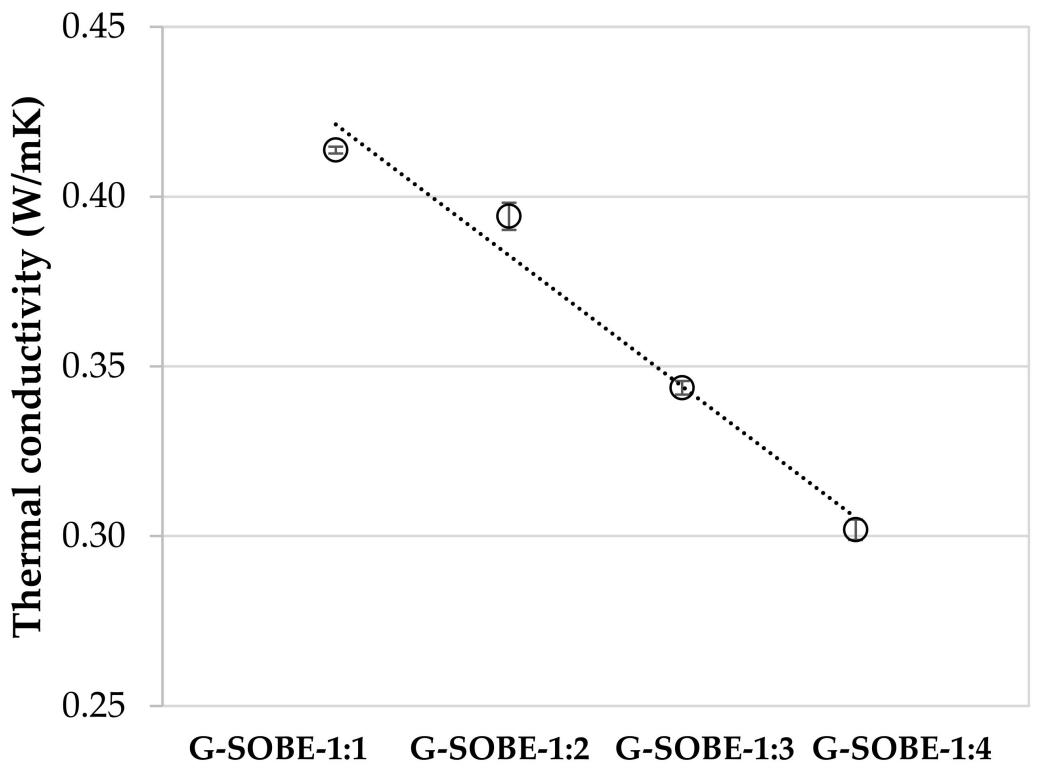

Figure 10. Thermal conductivity of samples cured for 28 days. 


\subsection{Microstructure of Geopolymer Binders}

SEM micrographs at different magnifications of geopolymer binders cured for 28 days are shown in Figures 11 and 12. At low magnification (220×, Figure 11) a homogeneous, dense and compact morphology can be observed in all samples. In any case, non-homogeneously distributed pores and some microcracks are visible. As expected from the density/porosity values, G-SOBE-1:1 samples seem more compact.

As the $\mathrm{Na}_{2} \mathrm{SiO}_{3} / \mathrm{NaOH}$ mass ratio decreases, more pores formed due to water evaporation during curing [93] are observed, possibly due to an increase in the water/binder ratio (Table 2).

At higher magnification $(2000 \times$, Figure 12$)$, sodium aluminosilicate gel with a spongy and globular morphology is visible in all samples. Its elemental chemical composition reveals the dominance of silicon, aluminum and sodium (zone 1 EDS analysis), as expected. In addition, unreacted SOBE particles with angular shapes are also visible. EDS analysis (zone 2) shows an abundance of silicon and aluminum, and smaller quantities of potassium, iron and magnesium. It can be observed that as the amount of sodium silicate decreases the geopolymers contain more unreacted SOBE particles and possess a higher porosity.
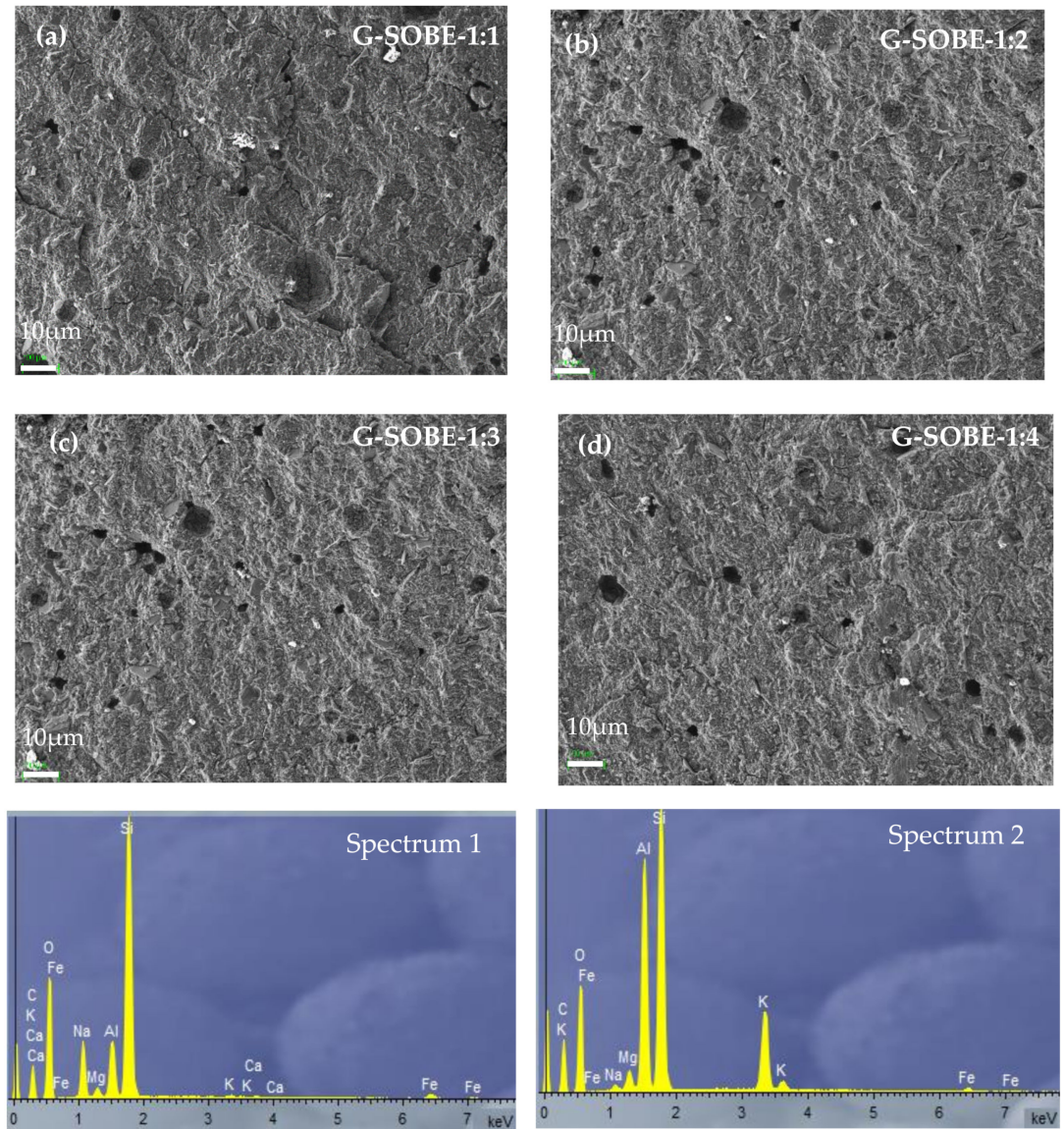

Figure 11. SEM micrographs (220× magnification) of geopolymers cured for 28 days. (a) G-SOBE-1:1; (b) G-SOBE-1:2; (c) G-SOBE-1:3; and (d) G-SOBE-1:4. 

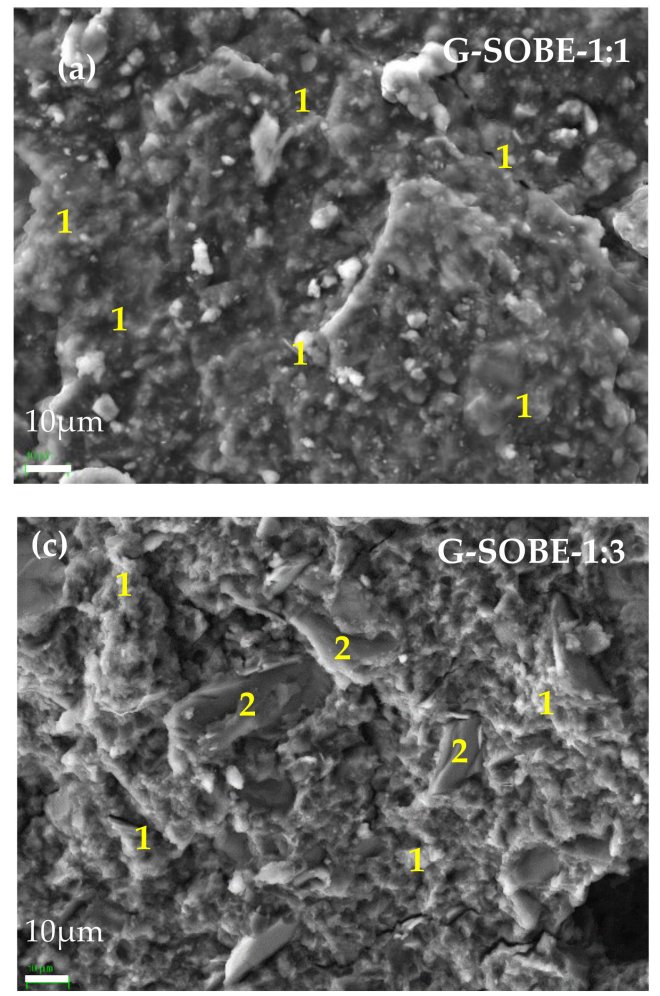
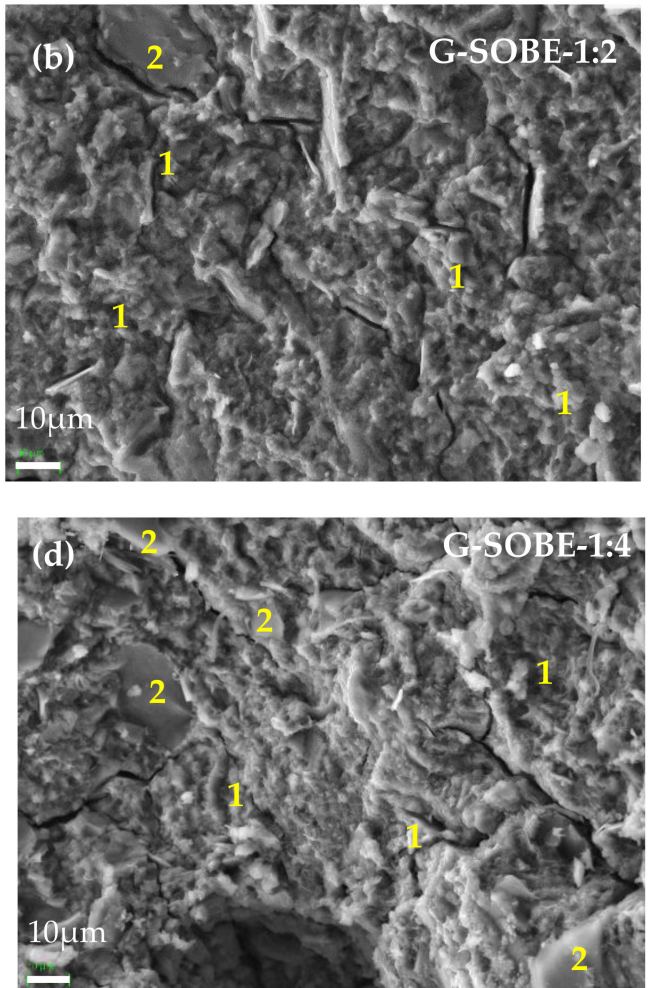

Figure 12. SEM/EDS micrographs (2000× magnification) of geopolymers cured for 28 days. (a) G-SOBE-1:1; (b) G-SOBE-1:2; (c) G-SOBE-1:3; and (d) G-SOBE-1:4.

\section{Conclusions}

Spent oil bleaching earths (SOBE), generated in the oil bleaching process, were used as a precursor of geopolymer binders prepared with activating solutions with distinct $\mathrm{Na}_{2} \mathrm{SiO}_{3} / \mathrm{NaOH}$ mass ratios. Physical, mechanical and thermal properties changed with the mentioned activator modulus. Flexural and compressive strengths, bulk density and thermal conductivity increase when the $\mathrm{Na}_{2} \mathrm{SiO}_{3} / \mathrm{NaOH}$ mass ratio increases, while total porosity and water absorption decrease. Maximal flexural $(8.4 \mathrm{MPa})$ and compressive (28.8 MPa) strength values were obtained in samples cured for 28 days at room temperature. The enrichment of soluble Si with the use of a higher amount of sodium silicate in the activator enhances the geopolymerization rate and extends it, generating higher compact and homogeneous microstructures due to the formation of a higher amount of threedimensional aluminosilicate hydrate [N-A-S-H] gel.

This work proved, for the first time, that SOBE can be used as a raw material of geopolymer binders, requiring pre-calcination at just $550{ }^{\circ} \mathrm{C}$ and sieving pre-treatment. This alternative contributes to the implementation of circular economy actions in this crucial activity.

Author Contributions: P.D.-P. and A.R.-E.: formal analysis; investigation; data curation; writingreview and editing. S.B.-R. and L.P.-V.: conceptualization; methodology; validation; formal analysis; writing-review and editing. D.M.T.: software, writing-review and editing. J.A.L.: validation; formal analysis; writing - review and editing; supervision. D.E.-Q.: conceptualization; methodology; validation; formal analysis; investigation; resources; data curation; writing-original draft; writing-review and editing; visualization; supervision; project administration; funding acquisition. All authors have read and agreed to the published version of the manuscript.

Funding: This research was funded by the project "GEOCIRCULA: Circular Economy in the manufacture of new geopolymeric composites: towards the goal of zero waste" (P18-RT-3504), funded by the Consejería de Economía, Conocimiento y Universidad of the Junta de Andalucía, with co-financing from the European Union through ERDF funds, from the incentive program for Universities and 
public research entities qualified as agents of the Andalusian Knowledge System, within the scope of the Andalusian Plan for Research, Development and Innovation (PAIDI 2020).

Institutional Review Board Statement: Not applicable.

Informed Consent Statement: Not applicable.

Acknowledgments: The authors greatly appreciate the collaboration of the Aceites del Sur Coosur, S.A. for supplying raw material. Technical and human support provided by Scientifical and Technical Instrumental Center (CICT) of Universidad de Jaén (MINECO, Junta de Andalucía, FEDER) is gratefully acknowledged.

Conflicts of Interest: The authors declare no conflict of interest.

\section{References}

1. Asociación de Productores de Cemento (ASOCEM). World Overview of the Cement Industry. 2018. Available online: http:/ / www.asocem.org.pe/archivo/files/Vision\%20General\%20de\%20la\%20Industria\%20del $\% 20$ Cemento $\% 20 \mathrm{y} \% 20$ sus $\% 20$ Principales\%20Actores.pdf (accessed on 22 May 2021).

2. Andrew, R.M. Global $\mathrm{CO}_{2}$ emissions from cement production. Earth Syst. Sci. Data 2018, 10, 195-217. [CrossRef]

3. Deja, J.; Uliasz-Bocheńczyk, A.; Mokrzycki, E. $\mathrm{CO}_{2}$ emissions from Polish cement industry. Int. J. Greenh. Gas Control. 2010, 4, 583-588. [CrossRef]

4. Zhou, W.; Yan, C.; Duan, P.; Liu, Y.; Zhang, Z.; Qiu, X.; Li, D. A comparative study of high- and low- $\mathrm{Al}_{2} \mathrm{O}_{3}$ fly ash basedgeopolymers: The role of mix proportion factors and curing temperature. Mater. Des. 2016, 95, 63-74. [CrossRef]

5. Ouellet-Plamondon, C.; Habert, G. Life cycle assessment (LCA) of alkali-activated cements and concretes. In Handbook of Alkali-Activated Cements, Mortars and Concretes; Elsevier: Amsterdam, The Netherlands, 2015; Volume 1, pp. 663-686.

6. Maddalena, R.; Roberts, J.; Hamilton, A. Can Portland cement be replaced by low-carbon alternative materials? A study on the thermal properties and carbon emissions of innovative cements. J. Clean. Prod. 2018, 186, 933-942. [CrossRef]

7. Robayo-Salazar, R.; Arcila, J.M.M.; de Gutiérrez, R.M.; Martínez, E. Life cycle assessment (LCA) of an alkali-activated binary concrete based on natural volcanic pozzolan: A comparative analysis to OPC concrete. Constr. Build. Mater. 2018, 176, 103-111. [CrossRef]

8. Davidovits, J. Geopolymer. Chemistry and Applications, 3rd ed.; Institut Geopolymer: Saint-Quentin, France, 2008 ; pp. 1-585.

9. Duxson, P.; Provis, J.L.; Lukey, G.C.; Van Deventer, J.S. The role of inorganic polymer technology in the development of 'green concrete'. Cem. Concr. Res. 2007, 37, 1590-1597. [CrossRef]

10. Grutzeck, M.W.; Siemer, D.D. Zeolites Synthesized from Class F Fly Ash and Sodium Aluminate Slurry. J. Am. Ceram. Soc. 2005, 80, 2449-2453. [CrossRef]

11. Hung, T.; Pernica, D.; Kroisová, D.; Bortnovsky, O.; Rylichova, V.; Louda, P. Composites Base on Geopolymer Matrices: Preliminary Fabrication, Mechanical Properties and Future Applications. In Advanced Materials Research; Trans Tech Publications Ltd.: Bäch, Switzerland, 2008; Volume 55, pp. 477-480.

12. Cheng, T.; Chiu, J. Fire-resistant geopolymer produced by granulated blast furnace slag. Miner. Eng. 2003, 16, 205-210. [CrossRef]

13. Bakharev, T. Resistance of Geopolymer Materials to Acid Attack. Cem. Concr. Res. 2005, 35, 658-670. [CrossRef]

14. Bell, J.; Gordon, M.; Kriven, W. Use of Geopolymeric Cements as a Refractory Adhesive for Metal and Ceramic Joins. Ceram. Eng. Sci. Proc. 2008, 24, 407-413. [CrossRef]

15. Khale, D.; Chaudhary, R. Mechanism of geopolymerization and factors influencing its development: A review. J. Mater. Sci. 2007, 42, 729-746. [CrossRef]

16. Bernal, S.A.; Provis, J.L. Durability of Alkali-Activated Materials: Progress and Perspectives. J. Am. Ceram. Soc. 2014, 97, 997-1008. [CrossRef]

17. Karakoç, M.B.; Türkmen, I.; Maraş, M.M.; Kantarci, F.; Demirboğa, R. Sulfate resistance of ferrochrome slag based geopolymer concrete. Ceram. Int. 2016, 42, 1254-1260. [CrossRef]

18. Davidovits, J. Mineral Polymers and Methods of Making Them. U.S. Patent No. 4.349.386, 1982. Available online: https: / / patentimages.storage.googleapis.com/56/1b/2e/9e4535535ead87/US4349386.pdf (accessed on 12 May 2021).

19. Barbosa, V.F.; MacKenzie, K.; Thaumaturgo, C. Synthesis and characterisation of materials based on inorganic polymers of alumina and silica: Sodium polysialate polymers. Int. J. Inorg. Mater. 2000, 2, 309-317. [CrossRef]

20. Samuel, R.; Puppala, A.; Radovic, M. Sustainability Benefits Assessment of Metakaolin-Based Geopolymer Treatment of High Plasticity Clay. Sustainability 2020, 12, 10495. [CrossRef]

21. Bonet-Martínez, E.; García-Cobo, P.; Pérez-Villarejo, L.; Castro, E.; Eliche-Quesada, D. Effect of Olive-Pine Bottom Ash on Properties of Geopolymers Based on Metakaolin. Materials 2020, 13, 901. [CrossRef]

22. Liew, Y.-M.; Heah, C.-Y.; Mustafa, A.B.M.; Kamarudin, H. Structure and properties of clay-based geopolymer cements: A review. Prog. Mater. Sci. 2016, 83, 595-629. [CrossRef]

23. Gómez-Casero, M.; Moral-Moral, F.; Pérez-Villarejo, L.; Sánchez-Soto, P.; Eliche-Quesada, D. Synthesis of clay geopolymers using olive pomace fly ash as an alternative activator. Influence of the additional commercial alkaline activator used. J. Mater. Res. Technol. 2021, 12, 1762-1776. [CrossRef] 
24. Novais, R.M.; Buruberri, L.H.; Ascensão, G.; Seabra, M.P.; Labrincha, J. Porous biomass fly ash-based geopolymers with tailored thermal conductivity. J. Clean. Prod. 2016, 119, 99-107. [CrossRef]

25. Tennakoon, C.; Sagoe-Crentsil, K.; Nicolas, R.S.; Sanjayan, J.G. Characteristics of Australian brown coal fly ash blended geopolymers. Constr. Build. Mater. 2015, 101, 396-409. [CrossRef]

26. Azad, N.; Samarakoon, S. Utilization of Industrial By-Products/Waste to Manufacture Geopolymer Cement/Concrete. Sustainability 2021, 13, 873. [CrossRef]

27. Torres, M.; Puertas, F. Waste glass in the geopolymer preparation. Mechanical and microstructural characterisation. J. Clean. Prod. 2015, 90, 397-408. [CrossRef]

28. Novais, R.M.; Ascensão, G.; Seabra, M.P.; Labrincha, J. Waste glass from end-of-life fluorescent lamps as raw material in geopolymers. Waste Manag. 2016, 52, 245-255. [CrossRef] [PubMed]

29. Nikolov, A.; Nugteren, H.; Rostovsky, I. Optimization of geopolymers based on natural zeolite clinoptilolite by calcination and use of aluminate activators. Constr. Build. Mater. 2020, 243, 118257. [CrossRef]

30. Davidovits, J. Geopolymer cement. Geopolymer Sci. Tech. 2013, 21, 1-11.

31. Cui, Y.; Wang, D.; Wang, Y.; Sun, R.; Rui, Y. Effects of the $\mathrm{n}\left(\mathrm{H}_{2} \mathrm{O}: \mathrm{Na}_{2} \mathrm{Oeq}\right)$ ratio on the geopolymerization process and 609 microstructures of fly ash-based geopolymers. J. Non Cryst. Solids 2019, 511, 19-28. [CrossRef]

32. Li, Z.; Zhang, S.; Zuo, Y.; Chen, W.; Ye, G. Chemical deformation of metakaolin based geopolymer. Cem. Concr. Res. 2019, 120, 108-118. [CrossRef]

33. Koleżyński, A.; Król, M.; Żychowicz, M. The structure of geopolymers-Theoretical studies. J. Mol. Struct. 2018, 1163, 465-471. [CrossRef]

34. Yusuf, M.O.; Palomo, A.M.W.; Grutzeck, M.W.; Blanco, M.T. Alkali-activated fly ashes: A cement for the future. Cem. Concr. Res. 1999, 29, 1323-1329. [CrossRef]

35. Luukkonen, T.; Abdollahnejad, Z.; Yliniemi, J.; Kinnunen, P.; Illikainen, M. One-part alkali-activated materials: A review. Cement Concr. Res. 2018, 103, 21-34. [CrossRef]

36. Komljenović, M.; Baščarević, Z.; Bradić, V. Mechanical and microstructural properties of alkali-activated fly ash geopol-620 ymers. J. Hazard. Mater. 2010, 181, 35-42. [CrossRef]

37. Weng, L.; Sagoe-Crentsil, K. Dissolution processes, hydrolysis and condensation reactions during geopolymer synthesis: 622 Part I-low Si/Al ratio systems. J. Mater. Sci. 2007, 42, 2997-3006. [CrossRef]

38. Lizcano, M.; Kim, H.S.; Basu, S.; Radovic, M. Mechanical properties of sodium and potassium activated metakaolin-624 based geopolymers. J. Mater. Sci. 2012, 47, 2607-2616. [CrossRef]

39. Van Jaarsveld, J.G.S.; van Deventer, J.S.J.; Lukey, G.C. The effect of composition and temperature on the properties of fly 626 ashand kaolinite-based geopolymers. Chem. Eng. J. 2002, 89, 63-73. [CrossRef]

40. Komnitsas, K.; Zaharaki, D. Geopolymerisation: A review and prospects for the minerals industry. Miner. Eng. 2007, 20, 1261-1277. [CrossRef]

41. Aventum. Available online: https://www.aventum.net/2017/05/16/tierras-de-blanqueo-de-aceites-hay-alternativas-al-63 Overtedero/ (accessed on 28 May 2021).

42. Loh, S.K.; Cheong, K.Y.; Salimon, J. Surface-active physicochemical characteristics of spent bleaching earth on soil-plant interaction and water-nutrient uptake: A review. Appl. Clay Sci. 2017, 140, 59-65. [CrossRef]

43. Tang, J.; Mu, B.; Zheng, M.; Wang, A. One-Step Calcination of the Spent Bleaching Earth for the Efficient Removal of Heavy Metal Ions. ACS Sustain. Chem. Eng. 2015, 3, 1125-1135. [CrossRef]

44. Tang, J.; Mu, B.; Wang, W.; Zheng, M.; Wang, A. Fabrication of manganese dioxide/carbon/attapulgite composites derived from spent bleaching earth for adsorption of $\mathrm{Pb}(\mathrm{ii})$ and Brilliant green. RSC Adv. 2016, 6, 36534-36543. [CrossRef]

45. Tang, J.; Mu, B.; Zong, L.; Zheng, M.; Wang, A. Facile and green fabrication of magnetically recyclable carboxyl-functionalized attapulgite/carbon nanocomposites derived from spent bleaching earth for wastewater treatment. Chem. Eng. J. 2017, 322, 102-114. [CrossRef]

46. Mana, M.; Ouali, M.S.; Lindheimer, M.; de Menorval, L.C. Removal of lead from aqueous solutions with a treated spent bleaching earth. J. Hazard. Mater. 2008, 159, 358-364. [CrossRef] [PubMed]

47. Kheang Loh, S.; James, S.; Ngatiman, M.; Yein Cheong, K.; May Choo, Y.; Soon Lim, W. Enhancement of palm oil refinery waste-Spent bleaching earth (SBE) into bio organic fertilizer and their effects on crop biomass growth. Ind. Crops Prod. 2013, 49, 775-781. [CrossRef]

48. Dijkstra, A.J. What to Do with Spent Bleaching Earth? A Review. J. Am. Oil Chem. Soc. 2020, 97, 565-575. [CrossRef]

49. Srisang, S.; Srisang, N. Recycling spent bleaching earth and oil palm ash to tile production: Impact on properties, utilization, and microstructure. J. Clean. Prod. 2021, 294, 126336. [CrossRef]

50. Eliche-Quesada, D.; Iglesias, F.A.C. Utilisation of spent filtration earth or spent bleaching earth from the oil refinery industry in clay products. Ceram. Int. 2014, 40, 16677-16687. [CrossRef]

51. Boey, P.-L.; Ganesan, S.; Maniam, G.P.; Ali, D.M.H. Ultrasound aided in situ transesterification of crude palm oil adsorbed on spent bleaching clay. Energy Convers. Manag. 2011, 52, 2081-2084. [CrossRef]

52. Fernández-Jiménez, A.; Palomo, A. Mid-infrared spectroscopic studies of alkali-activated fly ash structure. Microporous Mesoporous Mater. 2005, 86, 207-214. [CrossRef] 
53. UNE-EN 1015-11:2020. Methods of Test for Mortar for Masonary_Part 11: Determination of Flexural and Compressive Strength of Hardened Mortar; Asociación Española de Normalización: Madrid, Spain, 2020.

54. UNE-EN 1015-10:2020. Methods of Test for Mortar for Masonry_Part 10: Determination of Dry Bulk Density of Hardened Mortar; Asociación Española de Normalización: Madrid, Spain, 2020.

55. ISO 8302:1991. Thermal Insulation-Determination of Steady-State Thermal Resistance and Related Properties-Guarded Hot Plate Apparatus; International Standards Organization: Geneva, Switzerland, 1991.

56. Larson, A.C.; Von Dreele, R.B. General Structure Analysis System (GSAS). Los Alamos Natl. Lab. Rep. LAUR 2004, $96,748$.

57. Toby, B.H. EXPGUI, a graphical user interface forGSAS. J. Appl. Crystallogr. 2001, 34, 210-213. [CrossRef]

58. Thompson, P.; Cox, D.E.; Hastings, J.B. Rietveld refinement of Debye-Scherrer synchrotron X-ray data from $\mathrm{Al}_{2} \mathrm{O}_{3}$. J. Appl. Crystallogr. 1987, 20, 79-83. [CrossRef]

59. Viani, A.; Gualtieri, A.; Artioli, G. The nature of disorder in montmorillonite by simulation of X-ray powder patterns. Am. Miner. 2002, 87, 966-975. [CrossRef]

60. Gualtieri, A. Accuracy of XRPD QPA using the combined Rietveld-RIR method. J. Appl. Crystallogr. 2000, 33, 267-278. [CrossRef]

61. García-Lodeiro, I.; Fernández-Jiménez, A.; Blanco, M.T.; Palomo, A. FTIR study of the sol-gel synthesis of cementitious gels: C-S-H and N-A-S-H. J. Sol-Gel Sci. Technol. 2008, 45, 63-72. [CrossRef]

62. Yang, Y.; Jiang, J.; Hou, L.; Lu, Z.; Li, J.; Wang, J. Pore structure and properties of porous geopolymer based on pre-swelled bentonite. Constr. Build. Mater. 2020, 254, 119226. [CrossRef]

63. Gionis, V.; Kacandes, G.H.; Kastritis, I.D.; Chryssikos, G.D. On the structure of palygorskite by mid- and near-infrared spectroscopy. Am. Miner. 2006, 91, 1125-1133. [CrossRef]

64. Bergamonti, L.; Taurino, R.; Cattani, L.; Ferretti, D.; Bondioli, F. Lightweight hybrid organic-inorganic geopolymers obtained using polyurethane waste. Constr. Build. Mater. 2018, 185, 285-292. [CrossRef]

65. Rattanasak, U.; Chindaprasirt, P. Influence of $\mathrm{NaOH}$ solution on the synthesis of fly ash geopolymer. Miner. Eng. 2009, 22, 1073-1078. [CrossRef]

66. Jiang, J.; Yang, Y.; Hou, L.; Lu, Z.; Li, J.; Niu, Y. Facile preparation and hardened properties of porous geopolymer-supported zeolite based on swelled bentonite. Constr. Build. Mater. 2019, 228, 117040. [CrossRef]

67. Longhi, M.A.; Rodríguez, E.D.; Bernal, S.A.; Provis, J.L.; Kirchheim, A.P. Valorisation of a kaolin mining waste for the production of geopolymers. J. Clean. Prod. 2016, 115, 265-272. [CrossRef]

68. Yaseri, S.; Verki, V.M.; Mahdikhani, M. Utilization of high volume cement kiln dust and rice husk ash in the production of sustainable geopolymer. J. Clean. Prod. 2019, 230, 592-602. [CrossRef]

69. Rożek, P.; Król, M.; Mozgawa, W. Spectroscopic studies of fly ash-based geopolymers. Spectrochim. Acta Part A Mol. Biomol. Spectrosc. 2018, 198, 283-289. [CrossRef] [PubMed]

70. Król, M.; Rożek, P.; Mozgawa, W. Synthesis of the Sodalite by Geopolymerization Process Using Coal Fly Ash. Pol. J. Environ. Stud. 2017, 26, 2611-2617. [CrossRef]

71. Hajimohammadi, A.; Provis, J.L.; van Deventer, J.S. The effect of silica availability on the mechanism of geopolymerisation. Cem. Concr. Res. 2011, 41, 210-216. [CrossRef]

72. Criado, M.; Fernández-Jiménez, A.; Palomo, A. Alkali activation of fly ash: Effect of the $\mathrm{SiO}_{2} / \mathrm{Na}_{2} \mathrm{O}$ ratio: Part I: FTIR study. Microporous Mesoporous Mater. 2007, 106, 180-191. [CrossRef]

73. Barbosa, V.F.; MacKenzie, K. Thermal behaviour of inorganic geopolymers and composites derived from sodium polysialate. Mater. Res. Bull. 2003, 38, 319-331. [CrossRef]

74. Komnitsas, K.; Zaharaki, D.; Vlachou, A.; Bartzas, G.; Galetakis, M. Effect of synthesis parameters on the quality of con-struction and demolition wastes (CDW) geopolymers. Adv. Powder Technol. 2015, 26, 368-376. [CrossRef]

75. Kazea, C.R.; Yankw, J.N.; Nanae, D.A.; Tchakoutea, H.K.; Kamseu, E.; Melo, U.C.; Leonelli, C.; Rahierd, H. Effect of silicate modulus on the setting, mechanical strength and microstructure of iron-rich aluminosilicate (laterite) based-geopolymer cured at room temperature. Ceram. Int. 2018, 44, 21442-21450. [CrossRef]

76. Lecomte, I.; Henrist, C.; Liégeois, M.; Maseri, F.; Rulmont, A.; Cloots, R. (Micro)-structural comparison between geopolymers, alkali-activated slag cement and Portland cement. J. Eur. Ceram. Soc. 2006, 26, 3789-3797. [CrossRef]

77. Zhang, G.; Ke, Y.; He, J.; Qin, M.; Shen, H.; Lu, S.; Xu, J. Effects of organo-modified montmorillonite on the tribology performance of bismaleimide-based nanocomposites. Mater. Des. 2015, 86, 138-145. [CrossRef]

78. Anh, H.N.; Ahn, H.; Jo, H.Y.; Kim, G.-Y. Effect of alkaline solutions on bentonite properties. Environ. Earth Sci. 2017, 76, 374. [CrossRef]

79. Provis, J.L.; Lukey, A.G.C.; Van Deventer, J.S.J. Do Geopolymers Actually Contain Nanocrystalline Zeolites? A Reexamination of Existing Results. Chem. Mater. 2005, 17, 3075-3085. [CrossRef]

80. Leong, H.Y.; Ong, D.E.L.; Sanjayan, J.G.; Nazari, A. The effect of different $\mathrm{Na}_{2} \mathrm{O}$ and $\mathrm{K}_{2} \mathrm{O}$ ratios of alkali activator on compressive strength of fly ash based-geopolymer. Constr. Build. Mater. 2016, 106, 500-511. [CrossRef]

81. Ibrahim, M.; Johari, M.A.M.; Rahman, M.K.; Maslehuddin, M. Effect of alkaline activators and binder content on the properties of natural pozzolan-based alkali activated concrete. Constr. Build. Mater. 2017, 147, 648-660. [CrossRef]

82. Toniolo, N.; Rincon, A.; Roether, J.; Ercole, P.; Bernardo, E.; Boccaccini, A. Extensive reuse of soda-lime waste glass in fly ash-based geopolymers. Constr. Build. Mater. 2018, 188, 1077-1084. [CrossRef] 
83. Hanjitsuwan, S.; Hunpratub, S.; Thongbai, P.; Maensiri, S.; Sata, V.; Chindaprasirt, P. Effects of NaOH concentrations on physical and electrical properties of high calcium fly ash geopolymer paste. Cem. Concr. Compos. 2014, 45, 9-14. [CrossRef]

84. Glid, M.; Sobrados, I.; Ben Rhaiem, H.; Sanz, J.; Amara, A.B.H. Alkaline activation of metakaolinite-silica mixtures: Role of dissolved silica concentration on the formation of geopolymers. Ceram. Int. 2017, 43, 12641-12650. [CrossRef]

85. Hameed, A.M.; Rawdhan, R.R.; Al-Mishhadani, S.A. Effect of various factors on the manufacturing of geopolymer mortar. Arch. Sci. 2017, 1, 111.

86. Xu, H.; Van Deventer, J.S.J. The geopolymerisation of alumino-silicate minerals. Int. J. Miner. Process. 2000, 59, 247-266. [CrossRef]

87. Hardjito, D.; Wallah, S.E.; Sumajouw, D.M.J.; Rangan, B.V. Fly Ash-Based Geopolymer Concrete. Aust. J. Struct. Eng. 2005, 6, 77-86. [CrossRef]

88. Huiskes, D.; Keulen, A.; Yu, Q.; Brouwers, H. Design and performance evaluation of ultra-lightweight geopolymer concrete. Mater. Des. 2016, 89, 516-526. [CrossRef]

89. Yun, T.S.; Jeong, Y.J.; Han, T.-S.; Youm, K.-S. Evaluation of thermal conductivity for thermally insulated concretes. Energy Build. 2013, 61, 125-132. [CrossRef]

90. Pan, Z.; Feng, K.N.; Gong, K.; Zou, B.; Korayem, A.H.; Sanjayan, J.; Duan, W.H.; Collins, F. Damping and microstructure of fly ash-based geopolymers. J. Mater. Sci. 2012, 48, 3128-3137. [CrossRef]

91. Albitar, M.; Ali, M.M.; Visintin, P.; Drechsler, M. Durability evaluation of geopolymer and conventional concretes. Constr. Build. Mater. 2017, 136, 374-385. [CrossRef]

92. Zhang, Z.; Provis, J.L.; Reid, A.; Wang, H. Mechanical, thermal insulation, thermal resistance and acoustic absorption properties of geopolymer foam concrete. Cem. Concr. Compos. 2015, 62, 97-105. [CrossRef]

93. Rashad, A.M.; Sadek, D.M.; Hassan, H.A. An investigation on blast-furnace stag as fine aggregate in alkali-activated slag mortars subjected to elevated temperatures. J. Clean. Prod. 2016, 112, 1086-1096. [CrossRef] 